\title{
Analysis of the impact of physical factors on the germination energy and germination of common sunflower in the presence of petroleum products
}

\author{
(C) Darya V. Sergeeva,${ }^{1+}$ and Pyotr P. Purygin ${ }^{2 *}$ \\ ${ }^{1}$ Departmeny Technology of Freight and Commercial Work, Stations and Nodes. \\ Samara State University of Communications. Svobody St., 2B. Samara, 443066 Russia. \\ Phone: +7 (927)602-65-96.E-mail: dv.sergeeva@yandex.ru \\ ${ }^{2}$ Department of Organic Chemistry. Samara State University. Ak. Pavlova St., 1. Samara, 443011. Russia. \\ Phone:+7 (846) 334-54-59.E-mail: puryginpp2002@mail.ru
}

Keywords: sunflower, germination, germination energy, rhizome, oil product, seeds.

*Supervising author; ${ }^{+}$Corresponding author

\section{Abstract}

The stimulating effect of the magnetoplasma installation on old seeds is known, as a result of which their activation occurs, on untreated seeds - processing acts as a fungicide. In addition, ozonation with ultraviolet radiation has a bactericidal effect. In the work, pre-sowing treatment with a magnetoplasma installation of ordinary sunflower seeds in the presence of oil pollution is studied. Two parallel experiments were carried out on the germination of common sunflower in rolls of filter paper. The experiments were carried out for 7 days, and two indicators were recorded: germination energy (on the 3rd day of the experiment) and germination (on the 7th day). In the first experiment, the substrate contained an oil product - the state standard sample for the flash point of hydrocarbons and oils in a closed crucible (SSS FHO CC), and the second - kerosene in different concentrations $(0.5 \%, 0.9 \%, 2.9 \%, 4.7 \%)$. The effect of the permissible concentration of kerosene and the state standard sample for the flash point of hydrocarbons and oils in a closed crucible in the soil slightly affected the germination and germination energy of sunflower seeds. With an increase in the concentration of kerosene and SSS FHO CC germination energy and germination are reduced. Thus, with an increase in the concentration of kerosene to a high level of pollution, the germination energy is $0 \%$ (substrate with kerosene) and 4\% (SSS FHO $\mathrm{CC}-$ substrate). Seed germination is also significantly reduced $-5 \%$ (kerosene substrate) and $12 \%$ (SSS FHO $\mathrm{CC}$ - substrate).

\section{References}

[1] D.V. Sergeeva, and P.P. Purygin. Study of the influence of oil products on growth parameters and the development of the rhizome of sunflower seeds Helianthus annuus L. Butlerov Communications. 2017. Vol.52. No.12. P.124-128. DOI: 10.37952/ROI-jbc-02/17-52-12-124

[2] I.V. Kazantsev. Pollution and methods of soil purification from petroleum products in railway transport. In the collection: Bioecological local history: world, Russian and regional problems materials of the $3 \mathrm{rd}$ All-Russian scientific and practical conference with international participation, dedicated to the 85th anniversary of the Faculty of Natural Geography of the PSGA. 2014. P.28-33. (russian)

[3] I.N. Rusinova. The use of glauconite in the detoxification of soils contaminated with petroleum products. I.N. Rusinova, V.V. Slyusarenko, A.V. Rusinov. Technosphere Safety: Science and practice: Proceedings of the International scientific and practical conference. Saratov, LLC "KUBiK Publishing House". 2015. P.60-62. (russian)

[4] D.A. Rusinov, Yu.A. Kholopov. Methods for cleaning soils and soils contaminated with petroleum products in railway transport. In the collection: Innovations in environmental management and protection in emergency situations Materials of the III International Scientific and practical Conference. 2016. P.35-39. (russian)

[5] M.A. Ivanova, N.S. Chikina, and L.A. Zenitova Elimination of oil pollution. Butlerov Communications. 2012. Vol.29. No.3. P.1-12. ROI-jbc-02/12-29-3-1

[6] N.V. Ksenz, S.V. Kacheishvili. Analysis of electrical and magnetic effects on seeds. Mechanization and Electrification of Agriculture. 2000. No.5. P.30. (russian) 
[7] M.M. Shashurin. The effect of pre-sowing treatment of onion seeds (Allium fistulosum L.) with a constant magnetic field on the physiological and biochemical characteristics of its seedlings. Science and Education. 2016. No.4. P.119-123. (russian)

[8] V.F. Putko. Device for pre-sowing seed treatment. Patent of the Russian Federation 118161/13, 2012. No.20. 20.07.12.

[9] D.V. Sergeeva, and P.P. Purygin. Analysis of branching of sunflower roots under the influence of external factors. Butlerov Communications. 2019. Vol.60. No.11. P.75-78. DOI: 10.37952/ROI-jbc-02/1960-11-75

[10] GOST 29141-91 (ISO 664-90) Seeds of oilseeds. The allocation of samples for the analysis of medium samples: oilseeds: Sat. Standards. Moscow: Standartinform. 2010. (russian) 